\title{
THEORETICAL PRINCIPLES OF FORMATION OF PROFESSIONAL COMPETENCE OF FUTURE SPECIALISTS OF THE ECONOMIC BRANCH IN INSTITUTIONS OF HIGHER EDUCATION
}

\author{
Mariia Telovata \\ Doctor of Pedagogical Sciences, Professor Honored Worker of Education of Ukraine Head of the Department of Accounting \\ and Taxation National Academy of Statistics, Accounting and Audit, Kyiv \\ http://orcid.org/0000-0001-9514-1663 \\ e-mail: levochkomariya@gmail.com
}

\begin{abstract}
The necessity of studying the processes of formation and development of professional competence of future specialists of the economic branch in higher educational institutions (hereinafter: HEI) (in the conditions of education reforming in Ukraine and its approximation to the common European standards) is substantiated. The emphasis is placed on the fact that in today's conditions of development of Ukrainian society in the process of raising the level of professional training of future specialists of the economic branch, attention is paid to intellectual, moral, cultural development, creative self-realization of future specialists (economists, accountants, financiers, bankers), as well as formation and improvement of their professional competence. On the basis of the analysis of scientific works of well-known researchers in the field of philosophy, sociology, psychology, pedagogy, it is found that the concept of "professional competence" mainly means: the general culture of the specialist; the ability to think and act professionally; the degree of development of individual and professional qualities; a set of functions, rights and responsibilities of the specialist; readiness for professional activity.

The content of the concepts of "competency", "competence" and "professional competence" is specified. Their essential characteristics are defined, namely: "competency" is the general ability and capability of the future specialist of the economic branch, based on his skills and knowledge to realize himself in professional activity; "competence" is a complex personality trait (of the future specialist of the economic branch), which includes the results of knowledge, skills and abilities, and the capability to perform a professional role in accordance with specified requirements, taking into account the actual production situation. The professional competence of specialists of the economic branch is interpreted as a high potential of functional education and professional training for accounting and economic, financial, banking, organizational and managerial, analytical and scientific research activities in the field of economics in production, sphere of services, management and scientific research institutions.
\end{abstract}

Keywords: vocational education, economic education, professional competence of specialists of economic branch.

Introduction. In the conditions of the reform of the higher school of Ukraine and its approximation to the common European standards, it is necessary to note an increase in the gap between the requirements for the graduate of the HEI and the actual result of the professional training of future specialists. With the development of the market economy and the emergence of new professions requiring a high level of intellectual contents, with the change in the professionally qualifying functions of labor in general, there is an objective need to develop theoretical foundations and practical mechanisms for the professional training of students of economic vocation. Problems of modern higher education require to strengthen the practical component of all theoretical studies, pay attention to the measurement and 
evaluation of the professional training that has been achieved by real specialists, because the success of the implementation of reforms and, in the final decision, the economic and social development of society as a whole will depend on them. It is possible to solve these problems by means of a broader and scientifically based introduction of a competent approach in the study of the effectiveness of the professional activity of the future economist, accountant, financier, and banker. That's why, first we turn to the analysis of existing classifications of professional competencies, and then consider the possibility of structuring the professional training of future specialists through the system of their competencies (Levochko, 2008a, p. 120; Radkevich, 2011, p. 11; Romanova, 2010).

In today's conditions of development of Ukrainian society, in the process of raising the level of professional training of future specialists of the economic branch, attention is paid to intellectual, moral, cultural development, creative independence of the future specialist (economist, accountant, financier, banker), as well as their formation and improvement of professional competence.

Materials and methods. The concept of professional competence today is very relevant among scientists working to improve the professional training of future specialists of the economic branch (Levochko, 2008b, p. 96). A.Gorkunenko, I.Zarubinskaya, G.Kordiumov, M.Levochko and others have studied the problem of improving the training of future specialists of the economic branch for professional activity; the problem of the formation of professional competence was studied by domestic scientists (N. Bulgakov, T. Desiatov, E. Luzik, N. Morse, O. Pometun, G. Romanov, M. Telovata), foreign scientists (L. Morris, D. Ricken, F. Taylor)

The issues of professional competence, orientation, professional interest, professional orientation, the process of forming a conscientious attitude to work; the problem of personal qualities, as well as other categories and concepts are considered in the works of V. Astahova, I. Yermakova, E. Ziera, I. Zimnaya, N. Kuzmina, S. Klepko, V. Maslov, O. Ovcharuk, E. Pavlyutenkova, I. Sotabovska, V. Slastonina, G. Trotsko, V. Shadrikova, O. Khutorsky, Y. Yakuba and others. Studies of various sources have shown that the study of the problem of the professional training quality of the graduate of the HEI as a problem of development and the formation of his professional competence, have not found a separate handling.

In the course of the work, theoretical methods were used: analysis of scientific research in philosophy, sociology, psychology, pedagogy - to establish the essence, content and structure of professional competence of future specialists of the economic branch; deduction and induction - to determine the conceptual foundations of the research topic; synthesis and synthesis - to substantiate the methodological and methodological foundations of the research topic; analysis of definitions, formalization, generalization - to substantiate the conceptual apparatus of research and to formulate conclusions and recommendations.

The aim of the paper is to distinquish the theoretical foundations of professional competence of future specialists of the economic branch in HEI and determine the essential characteristics of the main concepts of the research.

Results and discussion. The entry of Ukraine into the world educational space requires the formation of qualitative educational services for the professional training of future specialists of higher qualification and their compliance with the conditions of the international labor market.

In conditions of economic restructuring, the modern paradigm of Ukraine's economic education involves the training of the highly skilled future specialist, and this process encompasses not only the development of his professional competence, but also the formation of internal readiness to master the profession. Conceptual ideas, that determine the priority of future specialists based on the competency paradigm of vocational education, are reflected in the National Strategy for the Development of Education of Ukraine for the period up to 2021, the Resolution of the Cabinet of Ministers of Ukraine "On Approval of the National Qualifications Framework", the Strategy for Sustainable Development "Ukraine 2020" .

Taking into account the important approach of development and formation of the professional competence of future specialists in HEI, the process of transformation of the economic system from planning to market requires not only changes in economic structures, but also changes in higher education. The main essence and complexity of this process is to provide the appropriate professional training of future specialists of the economic branch who will carry out this transformation. The provision of the set requirements raises the problem of the quality of training of future specialists of the economic branch (accountants, economists, financiers, bankers) (Levochko, 2008b, p. 96).

Although interest in the process of forming professional competence has grown recently, the professional competence of specialists of the economic branch remains an underdeveloped and theoretically poorly studied aspect; the problem of the formation of professional competence of future specialists of the economic branch is not given enough attention, despite the fact that specialists (accountants, 
financiers, economists, bankers) are among the most necessary professions in the modern world.

Taking into consideration the complex of theoretical positions, normative-legal documents it is necessary to focus on the educational-professional program of higher education, in which the competence of specialists of the economic branch is interpreted as "high potential of functional education and professional training for accounting and economic, financial, banking, organizational and managerial, analytical and research activities in the field of economics in production, sphere of services, management and scientific research institutions". On one hand, the industrial practice makes such requirements as a high intellectual level, possession of certain professional, practical skills to the specialists of the economic branch, and on the other hand it is the availability of proper accounting and economic experience (Levochko, 2008b).

In accordance with this or that kind of professional activity, domestic and foreign researchers distinguish between the concepts of "competence" and "professional competence". The introduction of the concept of "professional competence" is due to the breadth of its content, the integrity of the characteristics that enable such concepts as "professionalism", "qualification", "professional abilities", etc.

In pedagogical science, the concept of "professional competence" is considered as a set of knowledge and skills that determine the effectiveness of labor, namely: the amount of skills in solving problems; a combination of personal qualities and properties; a complex of knowledge and professionally meaningful personal qualities; vector of professionalization; the unity of theoretical and practical readiness for work; the ability to perceive complex activities.

In modern scientific literature, the capability to carry out any professional activity is defined by the term professional competence, which is understood as a complex integrated quality of the individual, and, it is not about the individual knowledge or skills, and not even about a set of separate procedures of the activity, but about the property that allows a person to carry out the activity in general (Levochko, 2008b, p. 97). This opinion is expressed quite greatly in the definition of J. Bergoen: "Competence is the ability and readiness to perform tasks. It can contain knowledge, skills, understanding and will"(Strelnikov, 1995).

Questions of the formation of professional competence as a component of the economic vocation in the professional training of students were considered at different levels and from different points of view by such domestic and foreign scholars as V. Adolff, V. Anishchenko, S. Amonashvili, E. Bondarevskaya,
V. Bolotov, A. Bermuss, T. Brahe, S. Budak, A. Vasiluk, S. Vershlovsky, O. Gazman, T. Dobudko, N. Efremova, G. Kovalchuk, N. Kopylova, K. Korsak, I. Kotov, N. Kuzmin, B. Krichevsky, A. Mihailichenko, A. Markova, O. Ovcharuk, R. Ovcharova, V. Serikov, V. Slastonin, L. Solomko, I. Taranenko, T. Ulasova, A. Hutorski, E. Short, Ye. Shyyanov, O. Shyyan and others.

In analyzing the scientific work of well-known researchers, we see that in the content of the concept of "professional competence" they fix:

$\checkmark$ the general culture of the specialist, reflected in the totality of scientific knowledge, valuable orientations, motives of activity, his cognition of the surrounding world and understanding of his place in it, the ability to develop creative potential (T. Brazhe);

$\checkmark \quad$ the ability to think and act professionally (A. Myshchenko, L. Mishchenko, E. Shiyanov);

$\checkmark$ degree of development of individual and professional qualities necessary for effective performance of professional activity in a concrete subject area, expressed in business and partner communication with people in solving their life problems (S. Bati?chev, E. Kholostova);

$\checkmark$ a set of functions, rights and responsibilities of the specialist (V. Afanasyev);

$\checkmark \quad$ readiness for professional activity (G. Trofimova).

There are different approaches to understanding the essence of professional competence. One of them is the functional-active approach (N.Kuzmina, A.Markova, V.Simonov, R.Shakurov, A.Shcherbakov, etc.), considering competence as the unity of theoretical and practical readiness to perform professional functions in which the main parameters of professional competence are given by the functional structure of professional activity (Levochko, 2008, p. 47).

Therefore, in professional training of the specialistprofessional, the today' actual task is such a professional training, the result of which is the ability to perceive market transformations, adapt to changes in life easily, develop his own competence. The future specialist, trained for the professional activity with a formed professional competence at a high level, will have the opportunity to analyze different situations more flexibly, react to changes in social, cultural, economic life of society mobilely, conduct effective business communication, take into account the basic economic laws in the process of professional activity, improve himself throughout all his life (Levochko, 2008b, p. 97). In defining the contents of the concept of professional competence, scientists consider it as a relationship of methodological, scientific-theoretical and practical knowledge (N. Kuzmina, I. Ogorodnikov, M. Skatkin, V. Slastonin), a combination of scientific- 
theoretical, constructive-technological, normative knowledge (V. Kraevsky), meaningful and operational knowledge (M. Skatkin), the unity of fundamental and instrumental knowledge (S. Arkhangelsky), theoretical and practical knowledge (Yu. Kulyutkin).

In summary, we will add that professional competence, due to the exceptional significance in the structure of personality qualities, serves as the object of increased research attention of foreign scientists (D. Britel, E. Gim?z, R. Kvasnytsia, V. Landesheer, P. Mercer, M. Robinson). All of the above mentioned scientific works have important theoretical and practical significance. At the same time, many issues related to the problem of the development of forming the professional competence of future specialists of the economic branch remain open (Levochko, 2008, p 48).

Conclusions. The pedagogical problem of developing professional competence of future specialists is not only to teach them to perform their professional functions, but also to inoculate them a systematic approach to the analysis of problem situations and the ability, based on this analysis to make optimal solutions that take into account the content and structure of their activities. The content of the concepts of "competency", "competence" and "professional competence" is specified. Their essential characteristics are defined, namely: "competency" is the general ability and capability of the future specialist of the economic branch, based on his skills and knowledge to realize himself in professional activity; "competence" is a complex personality trait (of the future specialist of the economic branch), which includes the results of knowledge, skills and the ability to perform a professional role in accordance with specified requirements, taking into account the actual production situation. The professional competence of specialists of the economic branch is interpreted as a high potential of functional education and professional training for accounting and economic, financial, banking, organizational and managerial, analytical and research activities in the field of economics in production, sphere of services, management and scientific research institutions.

\section{List of references}

Левочко, М.Т., 2008 а. Компетенція, як складова професійної діяльності спеціалістів економічного напряму в системі "коледж-ВНЗ". Науковий часопис Національного педагогічного університету ім. М.П. Драгоманова: збірник наукових праць, 8(18), с. 120-124. (Серія 16. "Творча особистість учителя: проблеми теорії і практики").

Левочко, М.Т., 2008 b. Показник професійних якостей фахівців економічного напряму професійна компетентність. В: Лузік, Е.В. та Акмалдінова, О.М., ред. Актуальні проблеми вищої професійної освіти України: матеріали науково-практичної конферениії. Київ, Україна, 20-21 Березень 2008. К.: НАУ.

Левочко, М.Т., 2008 с. Професійна компетентність фахівців у системі "коледж-університет". Науковий вісник кафедри ЮНЕСКО КНЛУ: збірник наукових праџь Киїського національного лінгвістичного університету, 16, с. 96-98. (Серія "Філологія, педагогіка, психологія").

Михеев, В. И., 1971. Моделирование и методы теории измерений в педагогике. М.: Прогресс.

Радкевич, В.О., 2012. Компетентнісний підхід до забезпечення якості професійної освіти і навчання. В: Радкевич, В.О., ред. Науково-методичне забезпечення професійної освіти і навчання: матеріали Всеукраїнської (звітної) науково-практичної конферениії. Київ, Україна, 23 Березень. Київ: Ін-т проф.-техн. освіти НАПН України.

Романова, Г.М., 2010. Дидактичне проектування як напрям психолого-педагогічної підготовки викладачів ВНЗ. вісник НТУУ "КПІ". Філософія. Психологія. Педагогіка, 1, с. 219-223.

Стрельников, В.Ю., 1995. Розвиток професійної компетентності вчителів у закладах післядипломної освіти. Кандидат наук. Центральний інститут післядипломної педагогічної освіти м. Києва.

\section{Translated \& Transliterated}

Levochko, M.T., 2008 a. Kompetentsiia, yak skladova profesiinoi diialnosti spetsialistiv ekonomichnoho napriamu v systemi "koledzh-VNZ" [Competence as a component of professional activity of specialists in the field of economics in the system of "college-university"]. Naukovyi chasopys Natsionalnoho pedahohichnoho universytetu im. M.P. Drahomanova: zbirnyk naukovykh prats. [Scientific journal of the National Pedagogical University named after M.P. Drahomanov: collection of scientific works], 8(18), s. 120-124. (Seriia 16. "Tvorcha osobystist uchytelia: problemy teorii i praktyky") [The creative personality of teacher: problems of theory and practice], [in Ukrainian].

Levochko, M.T., 2008 b. Pokaznyk profesiinykh yakostei fakhivtsiv ekonomichnoho napriamu profesiina kompetentnist [The indicator of professional qualities of specialists in the economic field of professional competence]. V: Luzik, E.V. ta Akmaldinova, O.M., red. Aktualni problemy vyshchoi profesiinoi osvity Ukrainy: materialy naukovo-praktychnoi konferentsii [Actual problems of higher professional education in Ukraine: materials of the scientific-practical conference]. Kyiv, Ukraina, 20-21 Berezen 2008. K.: NAU, [in Ukrainian].

Levochko, M.T., 2008 c. Profesiina kompetentnist fakhivtsiv u systemi "koledzh-universytet" [Professional competence of specialists in the system "college-university"]. Naukovyi visnyk kafedry YuNESKO KNLU: zbirnyk naukovykh prats Kyivskoho natsionalnoho linhvistychnoho universytetu [Scientific herald of the department of UNESCO KNLU: collection of scientific works of the Kiev national linguistic university], 16, s. 96-98. (Seriia "Filolohiia, pedahohika, psykholohiia" [Philology, Pedagogy, Psychology]), [in Ukrainian]. 
Miheev, V. I., 1971. Modelirovanie i metodyi teorii izmereniy v pedagogike [Modeling and methods of measurement theory in pedagogy]. M.: Progress, [in Russian].

Radkevych, V.O., 2012. Kompetentnisnyi pidkhid do zabezpechennia yakosti profesiinoi osvity i navchannia [Competency approach to ensuring the quality of vocational education and training.]. V: Radkevych, V.O., red. Naukovometodychne zabezpechennia profesiinoi osvity i navchannia: materialy Vseukrainskoi (zvitnoi) naukovo-praktychnoi konferentsii [Scientific and methodological provision of vocational education and training: materials of the All-Ukrainian (reporting) scientific-practical conference]. Kyiv, Ukraina, 23 Berezen. Kyiv: In-t prof.-tekhn. osvity NAPS Ukrainy, [in Ukrainian].

Romanova, H.M., 2010. Dydaktychne proektuvannia yak napriam psykholoho-pedahohichnoi pidhotovky vykladachiv VNZ [Didactic design as a direction of psychological and pedagogical preparation of teachers of universities]. Visnyk NTUU "KPI". Filosofiia. Psykholohiia. Pedahohika [Bulletin of the NTUU "KPI". Philosophy. Psychology. Pedagogics], 1, s. 219-223, [in Ukrainian].

Strelnykov, V.Iu., 1995. Rozvytok profesiinoi kompetentnosti vchyteliv u zakladakh pisliadyplomnoi osvity [Development of professional competence of teachers in institutions of postgraduate education]. Kandydat nauk. Tsentralnyi instytut pisliadyplomnoi pedahohichnoi osvity m. Kyieva, [in Ukrainian].

\title{
Теоретичні засади формування професійної компетентності майбутніх фахівців економічної галузі в закладах вищої освіти
}

\author{
Марія Теловата
}

доктор педагогічних наук, професор, заслужений працівник освіти України, завідувач кафедри обліку та оподаткування Національної академії статистики, обліку та аудиту, м. Київ

Реферат. Обгрунтовано необхідність вивчення процесів формування і розвитку професійної компетентності майбутніх фахівців економічної галузі в закладах вищої освіти (далі: ЗВО) в умовах реформування освіти в Україні та 3 метою їі наближення до загальноєвропейських стандартів. Акцентовано увагу на тому, що в сучасних умовах розвитку українського суспільства в процесі підвищення рівня професійної підготовки майбутніх фахівців економічної галузі увага приділяється інтелектуальному, моральному, культурному розвиткові, творчій самореалізації майбутніх фахівців (економістів, бухгалтерів, фінансистів, банкірів), а також формуванню та вдосконаленню у них професійної компетентності. На основі аналізу наукових робіт відомих дослідників у галузі філософії, соціології, психології, педагогіки з'ясовано, що поняття "професійна компетентність" здебільшого означає: загальну культуру фахівця; уміння мислити і діяти професійно; ступінь розвиненості індивідуально-професійних якостей; сукупність функцій, прав і відповідальності фахівця; готовність до професійної діяльності.

Уточнено зміст понять "компетенція", "компетентність" та "професійна компетентність". Визначено їх істотні характеристики, а саме: "компетенція" - загальна здібність і здатність майбутнього фахівця економічної галузі на основі його вмінь і знань реалізувати себе в професійній діяльності; "компетентність" - комплексна характеристика особистості (майбутнього фахівця економічної галузі), що включає результати знань, умінь і навичок та здатність виконувати професійну роль відповідно до визначених вимог з урахуванням реальної виробничої ситуації. "Професійна компетентність" фахівців економічної галузі трактується як високий потенціал функціональної освіти і професійної підготовки для обліково-економічної, фінансової, банківської, організаційно-управлінської, аналітичної і дослідної діяльності в галузі економіки на виробництві, у сфері послуг, в управлінні й науководослідних установах.

Ключові слова: професійна освіта, економічна освіта, професійна компетентність фахівців економічної галузі.

Received: 06 May 2019

Accepted: 24 May 2019 